\title{
Doğu Afrika’da Müslüman Kardeşler ve El-Islah Örneği
}

\author{
Mehmet Öztürk*
}

\section{Öz}

Müslüman Kardeşler (İhvan-1 Müslimin), Mısır'da, 1928 yılında, Hasan el-Benna tarafindan kurulmuştur. Kuruluşundan kısa süre sonra hem ülke içinde hem de ülke dışında kendisine çok sayıda taraftar bulan Müslüman Kardeşler; sadece kuruldukları yer olan Mısır'da değil, Lübnan, Filistin ve Suriye başta olmak üzere dünyanın değişik yerlerinde etkisini hissettiren bir hareket olmuştur. Bu çalışmanın amac1, böylesine aktif bir hareketin Doğu Afrika'daki etkilerinin nasıl olduğunu araştırmak ve Somali'deki el-Islah'ın bu hareketle ilişkisini tespit etmektir. Bunun için çalışmada nitel araştırma desenine uygun olarak Müslüman Kardeşler ve elIslah üzerinden örgüt incelemesi yapılmaktadır. Yapılan araştırma neticesinde Müslüman Kardeşler örgütünün etkisinin Doğu Afrika'da da hissedildiği ve özellikle Somali'de el-Islah olarak bilinen İslami hareketin, Mısır Kardeşleri ile yakın ilişkisi bulunurken, ülke içindeki diğer hareketlerden ayrıştığı tespit edilmiştir.

Anahtar Kelimeler: El-Islah, Eş-Şebab, İhvan-1 Müslimin, Somali, Sudan

Dr. Öğr. Üyesi, Aksaray Üniversitesi, TR, Uluslararası İlişkiler Bölümü, orcid.org/00000003-3556-9216,mehmetozturk@aksaray.edu.tr 


\title{
Muslim Brotherhood in East Africa and the Case of Al-Islah
}

\author{
Mehmet Öztürk*
}

\begin{abstract}
The Muslim Brotherhood (Ikhwan-i Muslimin) was founded in Egypt in 1928 by Hasan al-Banna. Shortly after its establishment, it found many supporters both inside and outside the country. Therefore, it became a movement that made its influence felt in Egypt, where it was founded, and in different parts of the world, especially in Lebanon, Palestine and Syria. This study aims to investigate the effects of such an active movement in Eastern Africa and determine the relationship of al-Islah in Somalia with this movement. For this purpose, organization analysis is carried out through the Muslim Brotherhood and al-Islah in accordance with the qualitative research pattern. As a result of the research, it was seen that the effect of the Muslim Brotherhood organization was also felt in Eastern Africa. In addition, it has been determined that the Islamic movement known as al-Islah in Somalia has a close relationship with the Egyptian Brotherhood while differing from other movements in the country.
\end{abstract}

Keywords: Al-Ikhwan Al-Muslimin, Al-Islah, Al-Shabaab, Somalia, Sudan

* Asst. Prof. Dr., Aksaray University, TR, Department of International Relations, orcid. org/0000-0003-3556-9216, mehmetozturk@aksaray.edu.tr. 


\section{Giriş}

1928 Mart ayında Hasan Ahmed Abdurrahman el-Benna (1906-1949) tarafindan Cem'iyyetü'l-İhvani'l-Müslimin ismiyle İsmailiye'de kurulan Müslüman Kardeşler kısa sürede kendisine çok sayıda taraftar bulmuştur. $\mathrm{Bu}$ süreçte öncelikle Ebu Savir, Port Said, el-Bahr es-Sağir, Süveyş gibi yerleşim yerlerinde şubeleşen Müslüman Kardeşler idari merkezini Ekim 1932'de Kahire'ye taşımıştır. ${ }^{1}$ Sonraki bir yıl içinde şubelerini ülke genelinde elliye çıkaran örgüt, ülke dışında ise Lübnan, Suriye ve Filistin'de örgütlenmeye başlamıştır. 1933'ten sonra her yıl düzenli kongreler gerçekleştirilerek örgütün stratejileri belirlenmeye başlanmıştır. Bunun yanında haftalık el-İhvanü'l-Müslimun Gazetesi (1933-1938), enNezir Dergisi (1938-1939) ve Risaletü'l-Mü’temeri'l-Hamis (1939'da elBenna'nın örgütün amaç, davet ve faaliyetlerini aktardığı konuşma metni) gibi yayınlar çıkartılmıştır. ${ }^{2}$

Müslüman Kardeşler, kuruluşunun ilk yıllarında daha çok apolitik, dini reform amaçlayan ve sosyal yardımlaşma kuruluşu niteliğindedir. İlk on yılında ülke içinde hiçbir parti ve kuruluşun yanında ya da karşısında olmamakla beraber hareketin davetini siyasi partiler ve devlet yöneticilerine aktarmayı amaçlamıştır. Söz konusu davette İslamın hükümlerinin yerine getirilmesinden ve sömürgecilere firsat verilmemesinden söz edilmiştir. Ayrıca "particiliğe son vermek ve milletin siyasi enerjisini tek bir yöne yönelterek tek bir saf etrafında birleştirmek" gerektiği ifade edilmiştir. $\mathrm{Bu}$ bağlamda Müslüman Kardeşlerin temel yaklaşımlarını, politikalarını duyurmak amaciyla ve anayasal sınırlar içerisinde kalmak şartıyla her türlü propaganda araçlarının da kullanılması gerektiği belirtilmiştir. ${ }^{3}$

1941 yılındaki örgütün 6. Kongresi'nde Mısır'da yapılması planlanan seçimlere katılma kararı almakla birlikte Mustafa el-Nahhas'la yapılan görüşmelerden sonra Benna, seçimlere katılmaktan vazgeçmiştir. Bunun karşılığında Müslüman Kardeşlerin faaliyetleri ve talepleri konusunda bir takım tavizler alabilmiştir. Bununla birlikte el-Benna'nın

Hasan el-Benna, Hatıralarım (Müslüman Kardeşler), çev. M. Beşir Eryarsoy (İstanbul: Beka Yayınc1lık, 2019), 129-184.

2 İbrahim Beyyümi Ganim, "İhvan-1 Müslimin," Türkiye Diyanet Vakfi İslâm Ansiklopedisi 21 (İstanbul: TDV Yayınları, 2000), 580-581.

3 Hasan el-Benna, Risaleler, çev. Mehmet Eren ve Mehmet Akbaş (İstanbul: Nida Yayıncıl1k, 2016), 223-318; El-Benna, Hatıralarım (Müslüman Kardeşler), 371-446. 
sonraki Mısırlı yöneticilerle arasının açılması, hareketin etkisinin artması ve bilhassa sömürgeciliğe karşı gerçekleştirilen protestolar, Müslüman Kardeşlere yönelik baskıları ve yasaklamaları beraberinde getirmiştir. ${ }^{4}$ Nitekim el- Benna, İngilizlerin baskıları sonucu 1941 Mayısında Kahire'den ayrılma kararı almak zorunda kalmıştır. Bunu ise Ekim ayında onun ve diğer üyelerin tutuklanmaları izlemiştir. Söz konusu devlet tedbirleri, araya İkinci Dünya Savaşı'nın girmesiyle gevşetilmiştir. Bu sayede yeniden aktif hale gelen örgütün, hızla üye sayısı ve etkinliği artmış, ayrıca gizli paramiliter bir kola da sahip olmuştur. ${ }^{5}$

Savaş sonrası siyasi seçkinlere güvensizlik hisseden dindar Mısır halkı için cazip hale gelen Müslüman Kardeşlerin, özellikle İngiliz karşıtlığı ve Filistin davasına destek vermeleri, Mısırlı milliyetçileri de derinden etkilemiştir. ${ }^{6}$ Müslüman Kardeşlere yönelik baskıların arttı̆̆ 1954-1971 arasında örgüt; Seyyid Kutub'un başını çektiği radikaller ile kurucu lider el-Benna'dan sonra yaklaşık 20 yıl harekete başkanlık eden Hasan İsmail el-Hudaybi'nin öncülügünü yaptığı 1lımlılar arasında kalsa da günümüzde daha 1lımlı bir noktada olduğu ve genellikle şiddet içeren faaliyet gerçekleştirmediği öne sürülmektedir. ${ }^{7}$ Ayrıca Mursi dönemi Mısır'1, Sudan ve Gazze Şeridi'nde Hamas gibi istisnalar hariç tutulacak olursa devlet gücünü tamamen kontrol ettiği söylenemeyen örgütün, kendine özgü bir örgütlenme şekli olmakla birlikte tamamen bir merkezden yönetildiği de söylenemez. ${ }^{8}$

Bu çalışmada Müslüman Kardeşlerin Doğu Afrika'daki etkilerinin nası1 olduğu araştırılmaktadır. Ayrıca bu örgütün bölgedeki rolü spesifik bir örnek oluşturması bakımından Somali'deki el-Islah hareketi üzerinden incelenmektedir. $\mathrm{Bu}$ çalışmanın öne sürdüğü argümanlardan birisi

4 Richard P. Mitchell, The Society of The Muslim Brothers, (New York: Oxford University Press, 1993), 21-23.

5 Ziad Munson, "Islamic Mobilization: Social Movement Theory and the Egyptian Muslim Brotherhood," The Sociological Quarterly 42, no. 4 (2002): 4-5.

6 Ana Belén Soage ve Jorge Fuentelsaz Franganillo, "The Muslim Brothers in Egypt," içinde The Muslim Brotherhood: The Organization and Policies of a Global Islamist Movement, ed. Barry Rubin (New York: Palgrave Macmillan, 2010), 40.

7 Barbara H.E. Zollner, The Muslim Brotherhood: Hasan al-Hudaybi and Ideology (New York: Routledge, 2009), 1.

8 Barry Rubin, "Introduction," içinde The Muslim Brotherhood: The Organization and Policies of a Global Islamist Movement, ed. Barry Rubin (New York: Palgrave Macmillan, 2010), 1. 
Müslüman Kardeşler hareketinin etkisinin hissedildiği yerlerden birisinin de Doğu Afrika olduğudur. Bir diğer argüman, Somali'de el-Islah olarak bilinen İslami örgütün Somali'nin Müslüman Kardeşleri olarak bilindiği ve bölgedeki diğer ilişkili hareketlerden farklı bir yapısının bulunduğuna ilişkindir. Çalışmada bu argümaları doğrulayabilmek ve açıklayabilmek için öncelikle Müslüman Kardeşlerin ideolojisi ve yayılım aşamaları -kısmen örgüt sosyolojisi ve toplumsal hareket teorisi ile ilişkilendirilerekincelenecektir. İkinci olarak, Müslüman Kardeşlerin Doğu Afrika'da (bilhassa Sudan ve Somali'de) nasıl bir varlık gösterdiği araştırılacaktır. Son olarak, Somali üzerine eğilerek bu ülkedeki el-Islah'ın yapısı, ülkedeki diğer gruplarla ayrışan yönleri ve Mısırlı Kardeşlerle ilişkisi ortaya çıkartılmaya çalışlacaktır.

\section{Müslüman Kardeşlerin İdeolojisi ve Yayılması}

İslam'ın Hanbeli mezhebine bağlı Müslüman Kardeşlerin odaklandığ1 başlıca alanlar; Mısır'ın kolonilerce tahakkümü, Mısır halkının yoksulluğu ve bireysel ahlakın azalması olmuştur. ${ }^{9}$ Müslüman Kardeşler, seküler yaşamı benimseyerek İslam'dan uzaklaşan halkın ahlaki çöküşe geçtiğini savunur. İslam'a sıkı sıkıya sarılmanın, onların hem yoksulluktan hem de sömürgeci Batı hegemonyasından kurtulmalarında başlıca rol oynayacağını iddia eder. Bu bakımdan "adalet, doğruluk, iktidar" retoriğini öne çıkartarak hayatın her alanında İslam'a uygun bir hayat tarzını benimsemiştir. ${ }^{10}$ Örgütün ideolojisi özellikle Batı emperyalizmden Mısır'ın kurtarılması bağlamında öncelikle ünlü İslam düşünürü Cemaleddin Afgani'den etkilendiği görülmektedir. Buradan hareketle İslam'ın esasında demokratik olduğu ve modern dünyanın sorunlarını çözebileceği iddiasıyla İslami bir devlet anlayışı benimsenmiştir. Bu bağlamda seküler yaşam tarzının ahlaksızlığa, yoksulluğa ve tahakküme yol açtığı gerekçesiyle sekülerizmle arasına mesafe koymuştur. İslami kuralların sıkı bir şekilde uygulanması ve bu konularda devlet müdahalesine sıcak yaklaşılmasının yanı sıra

Munson, "Islamic Mobilization," 6.

10 Mehmet Dalar, "Misır'da Müslüman Kardeşler Hareketinin Demokrasi Anlayışı ve Sisteme Etkisi,” Alternatif Politika 1 (Kasım 2010): 54. 
İslam tarihinin araştırılması, Kuran'ın ezberlenmesi (hafızlık), Arapça dilinin kullanılması ve Arap devletleriyle yakın ilişkiler geliştirilmesi gibi faaliyetler de örgütün ideolojisinde kendisine yer bulmuştur. ${ }^{11}$ Başta Misır olmak üzere İslam toplumlarında, sömürüleştirme ve dinin yorumlanması konusunda kendi çözümlerini üretememekten kaynaklanan reformist arayış, Müslüman Kardeşlerin ilgisini çekmiştir. Bu noktada İslam dininin siyasi, iktisadi ve sosyal mecralardaki sorunları çözebildiğini düşünen Cemaleddin Afgani'nin (1838-1997) yanı sıra Reşit Rıza (18631935) ve Muhammed Abduh (1849-1905) gibi reformist düşünürler de Müslüman Kardeşlerin kuruluşunda ve ideolojisinde etkili olmuştur. İslam toplumlarının neden geri kaldığı üzerine eğilen bu düşünürlerden örneğin Abduh, kadınlara da erkeklerle eşit haklar tanınmasını, Batı'nın teknoloji ve ilminin alınarak Batılaşmayı ve eğitimde revizyonu savunmuştur. Rıza ise daha çok İslam'ın ilk ortaya çıktığı halinin muhafaza edilerek onu günümüze taşıma düşüncesinde olmuştur. Bir bütün olarak bakıldığında ise Müslüman Kardeşlerin ideolojisinin reformcu İslam anlayışına dayandığ ve 20. yüzyıla damga vuran bir hareket olduğu göze çarpmaktadır. ${ }^{12}$

$\mathrm{Bu}$ görüşlerden ilham alan Müslüman Kardeşlerin kurucusu Hasan el-Benna, bireyden aileye, aileden topluma uzanacak dine uygun bir değişimin şart olduğunu ve sosyal alanda Müslümanların güçlendirilmesi için toplumsal alanda örgütlenmeye ihtiyaç olduğunu düşünmüsstür. İslam toplumlarının Batılılaşmış Müslüman aydınlar ve Avrupalı koloniciler nedeniyle geri kaldığını düşünen el-Benna öncelikli olarak İslam coğrafyasının özgürleşmesi gerektiğini öne sürmüştür. Bu bağlamdaki görüşlerini "Risaleler" isimli eserinde de işlemiştir. ${ }^{13}$

El-Benna, İslami anlayış bakımından Selefiyye ve Islahı benimsemiştir. Selefiyye itikadi meselelerde Kur' an ve Sünnet'in lafzına uygun ve te'vili reddeden anlayışı, Islah ise İslami değerleri, yaşam tarzı ve inanç bağlamında

Munson, "Islamic Mobilization," 7.

12 Tayyar Ar1 ve Engin Koç, "Müslüman Kardeşler Hareketinin Misir Hükümeti İle Paradoksal İlişkilerinin Analizi: 1931-1970," Dumlupınar Üniversitesi Sosyal Bilimler Dergisi 42 (2014): 226; İrfan Kaya Ülger, "Müslüman Kardeşler Teşkilatının İdeolojisi ve Misır Siyaseti Üzerindeki Etkileri," Klrlkkale Üniversitesi Sosyal Bilimler Dergisi 6, no. 2 (2016): 145.

13 Ülger, "Müslüman Kardeşler Teşkilatının İdeolojisi," 145-146; El-Benna, Risaleler, 151-189. 
yeniden canlandırma (ihya etme) gayesindeki fikir ve eylemleri içerir. ElBenna'nın 1949'da suikasta uğramasının ardından Müslüman Kardeşler hareketi, radikaller ve 1lımlılar olarak ikiye ayrılmıştır. Radikalleri Sâlih Aşmâvî ve ed-Da've Dergisi, 1lımlıları ise Saîd Ramazan ve el-Müslimûn Dergisi temsil etmiştir. Bununla birlikte Benna'nın İslam'da sosyal adalet anlayışı harekete 1951'de Seyyid Kutub'un katılmasını beraberinde getirmiş ve Kutub 1990'l y yllara kadar harekette derin izler bırakmıştır. ${ }^{14}$ Kulluk bilinciyle hareket edip yaşayan insanların oluşturduğu toplumu Müslüman toplum (buna uygun olmayanları cahiliye toplum) olarak gören, İslam inancında "hakimiyetin, her alanda Allah'ın mutlak hükümranlığını ifade ettiğini" ve bu bağlamda meşruiyetini Allah'tan almayan yönetimlerin tağut (zorba) olduğunu düşünen Kutub'un etkisi, Müslüman Kardeşlerin yanı sıra tüm çağdaş İslami hareketlerde derin izler bırakmıştır. ${ }^{15}$

Hasan el-Benna ve Seyyid Kutub'un Müslüman Kardeşlerin ideolojik zeminin inşasında önemli etkileri görülmekle beraber bu hareketin varlığını sürdürebilmesinde ve yeri geldiğinde kısmi revizyonlar yapabilmesinde Hasan el-Hudaybi'nin etkisinin olduğu öne sürülmektedir. Ayrıca Müslüman Kardeşler arasında 1980'lerin ortalarından günümüze kadar uzanan dönemde Vasatiyye (orta yol) isimli ideolojik bakışın öne çıtığı görülmektedir. Yusuf el-Kardavi'nin öncülük ettiği bu orta yol, laiklik ile şiddeti meşru gören radikal İslami akımlar arasında 1lımlı bir duruşu yansitır. Diğer bir deyişle modern dünya ile uyumlu, hoşgörülü ve İslam adına şiddet kullanmaya karşı bir dini anlayışı barındırır. Hareket içindeki bu dönüşüm Batıya ait bazı değerlerin İslam'la çelişmediği, dolayısıyla toptancı bir bakışla Batı karşıtı bir pozisyonun terkedilmeye başlandığı bir anlayışı beraberinde getirmiştir. ${ }^{16}$ Dahası böyle bir dönüşüm İslam hukuku sınırları içinde anayasal hükümeti ve sivil özgürlükleri harmanlayan bir sivil devleti çağrıştırmaktadır. Bu anlamda demokrasiye olan inancın arttığı görülmektedir. Hatta örgütün siyasal sistem içinde faaliyet gösterip demokratik reform talepleri, siyasi seçmenlerini de artırmıştır. ${ }^{17}$

14 İbrâhim El-Beyyûmî Gānim, "Hasan El-Bennâ," Türkiye Diyanet Vakfi İslâm Ansiklopedisi 16 (İstanbul: TDV Yayınları, 1997), 309.

15 Ülger, “Müslüman Kardeşler Teşkilatının İdeolojisi,” 146.

16 a.g.e., 147.

17 Chris Harnisch ve Quinn Mecham, "Democratic Ideology in Islamist Opposition? The Muslim Brotherhood's 'Civil State," Middle Eastern Studies 45, no. 2 (2009): 189194. 
Dolayısıyla kuruluşundan günümüze Müslüman Kardeşlerin ideolojisi ve pratiği yekpare olduğu söylenemese de Misır toplumunun önemli bir kesimi tarafından destek gördüğü söylenebilir. Bu durum özellikle Hüsnü Mübarek rejiminin 11 Şubat 2011'de sona ermesinden sonra yapilan seçimleri Özgürlük ve Adalet Partisi/FJP temsilinde Muhammed Mursi liderliğindeki Müslüman Kardeşlerin kazanmasında görülmektedir. Ancak hareketin yöneticilerinin bu süreçte pragmatizmden uzak söylemleri, siyasal deneyim eksikliği, ideolojilerini siyasete birebir aktarım yapmaya çalışmaları, bürokraside etkin olan eski rejim güçlerinin varlığını küçümsemeleri en önemli eksiklikleri olarak görülmektedir. ${ }^{18}$

Öyle ki özgür ve demokratik olarak seçilmiş ilk cumhurbaşkanı olan Mursi, 3 Temmuz 2013’te, kendisinin Genel Kurmay Başkanı olarak atadığ1 Abdülfettah es-Sisi’nin liderliğini yaptığ askeri darbe sonrası devrilmiş ve pek çok Müslüman Kardeşler üyesi tutuklanmıştır. Müslüman Kardeşlerin üyeleri bu durumdan dolayı eski rejim güçlerini (derin devleti) suçlarken, Khalil al-Anani, Mursi liderliğinin aceleci tavrının ve hesaplama yanlışlığının bunda etkili olduğunu öne sürmektedir. ${ }^{19}$ Bununla birlikte bu darbede iç faktörler kadar dış faktörlerin de göz ardı edilmemesi gerektiği, Arap İsyanları sürecinin hatırlattığ bir olgudur. $^{20}$

Mursi'den sonra teşkilatın Mısır'daki varlığı ve geleceği; mevcut rejimle uzlaşma, ortadan kalkma/parçalanma ya da yeniden icat/geri dönüşş şeklinde farklı seçenekler üzerinden tartışılmaya devam etmektedir. Ancak Mursi ile beraber görülmüştür ki Mısır'da İslami bir siyasi ve sosyal düzen kurma hayali, Mısır toplumunun sonraki dönemlerde yeniden gerçekleştirmeyi deneyebileceği bir olgu olarak önemli bir referans olmuştur. ${ }^{21}$

Müslüman Kardeşlerin 2000-2010 arasındaki tecrübesi yani dini ve ahlaki düşünce eksenini sürdürmekle beraber bunu siyaset alanına taşıma uğraşları ve Mursi döneminde iktidara gelindiğinde bu yöndeki faaliyetlerin

18 Ülger, "Müslüman Kardeşler Teşkilatının İdeolojisi," 147.

19 Khalil al-Anani, "Upended Path: The Rise and Fall of Egypt's Muslim Brotherhood," Middle East Journal 69, no. 4 (Sonbahar 2015): 527.

20 Muhittin Ataman, “Arap Dünyasında Değişim Talebi Devam Ediyor,” Anadolu Ajansı, 23 Aralık 2019, Son erişim tarihi: 27 Şubat 2021, https://www.aa.com.tr/tr/analiz/ arapdunyasinda- degisim-talebi-devam-ediyor/1681527

21 Ashraf El-Sherif, The Muslim Brotherhood and the Future of Political Islam in Egypt (Washington, DC: Carnegie Endowment for International Peace, 2014), 27-28. 
sürdürülmesi, Müslüman Kardeşlerin 1lımlı bir siyaset yürütebilen bir harekete dönüşebildiğini göstermiştir. Bununla beraber Müslüman Kardeşlerin ideolojik bağlamı dikkate alındığında şiddet içermese bile Mısır'da şeriata dayalı bir siyasal rejim oluşturmak istemesi, örneğin Uluslararası Kriz Grubu gibi düşünce kuruluşlarınca politik, misyoner ve cihatçı bir çerçevede değerlendirilmiştir. Bu İslami hareketin farklı kolları olmakla beraber neticede İslami bir devlet olma arzusu noktasında bu kolların birleştikleri öne sürülmüştür. ${ }^{22}$

Müslüman Kardeşlerin, Hizb al-Tahrir ile Ürdün dışında pek bir teması bulunmadığı, el-Kaide ile ise Amerika karşıtlığ1 ve ideologlarına sayg1 dışında pek bir ortak noktalarının bulunmadığı, hatta birbirlerini rakip gördükleri öne sürülmektedir. Müslüman Kardeşler ile el-Kaide üç bağlamda kıyaslanabilir. Birincisi, aralarında fili ve ideolojik şiddetli bir çatışma olmasa da kitle desteği ve devlet iktidarı için mücadele eden rakip iki akımdır. İkincisi, el-Kaide ABD ve İsrail gibi uzak düşmana saldırmaya, Müslüman Kardeşler ise İsrail karşıtı (Hamas’ı destekleyen pozisyonda) olmasına karşın yakın düşmana (Arap hükümetlerinde değişime) odaklanmaktadır. Üçüncüsü, el-Kaide sadece silahlı mücadeleye eğilimliyken, Müslüman Kardeşler ise esnek ve uzun vadeli amaçlar taşımaktadır. ${ }^{23}$

Kardeşliğin tam üyesi olabilmek sekiz yılı bulabilmektedir. Aday üyeler, muhibten (takipçi) muayyad'a (destekçi) muntasib'e (bağlı) muntazim'e (organizatör) ve tam teşekküllü Kardeş'e kadar yükselebilmektedirler. ${ }^{24}$ Müslüman Kardeşlerin 1930'lar sonrası ülke içinde ve dışında taraftar toplayabilmesinin nedenleri üzerine literatürde yeterince araştırma olmasa da Emile Durkheim'ın toplumsal değişim ve anomali üzerine düşünceleri bu noktada yol gösterici olabilir. $\mathrm{Bu}$ bağlamda değerlendirildiğinde geleneksel inançlara duyulan inancın, nüfus artışının ve kentleşme ve sanayileşmenin getirdiği anormal sosyal koşulların, bu harekete yönelik

22 Isaac Kfir, "Islamic Radicalism in East Africa: Is There a Cause for Concern?," Studies in Conflict ve Terrorism 31, no. 9 (2008): 830.

23 Barry Rubin, "Comparing Three Muslim Brotherhoods," içinde The Muslim Brotherhood: The Organization and Policies of a Global Islamist Movement, ed. Barry Rubin (New York: Palgrave Macmillan, 2010), 7-8.

24 Hussein Solomon, "Political Islam: An African Perspective," Contemporary Review of the Middle East 2, no. 1-2 (2015): 92-93. 
talebi artırdığg düşünülmektedir. Ayrıca geleneksel yaşam ile modern yaşam arasındaki gerilim ve göreceli yoksunluk yine bu hareketin popüler hale gelmesini açılamada kullanılabilecek kavramsallaştırmalar olabilir. Bununla birlikte Ziad Munson'a göre; gerginlik (modern-geleneksel arasındaki), anomi ve göreceli yoksunluk, kısmi olarak açıklama yapabilse de örneğin işin içine psikolojik faktörlerin girmesi ve test olanağının kısıtll olması, tam bir çıkarım yapmayı zorlaştırmaktadır. ${ }^{25}$

Müslüman Kardeşler tabiatıyla İslami yönü ağır basan bir toplumsal harekettir. Kavram olarak "toplumsal hareketler"; statükoya, otoriteye ya da kültürel değerlere, "kolektif, organize, sürdürülebilir ve kurumsal olmayan" bir karşı duruşu tanımlamak için kullanılmaktadır. Bunlarda, "sembol, söylem ve pratiğe dayalı seferberlik" ile aktivizmin desteklenmesi amaçlanır. Toplumsal hareketlerin bir parçası olan İslamcı hareketler ise İslami anlayışa uygun kollektifliği destekleme ve tutarl1lık sergileyen amaçlar bakımından örtüşmekle beraber örgütlenme şekilleri, araçlar, taktik ve zamanlama bakımından ayrışabilmektedirler. Örneğin, İslamcı hareket (İslamcı aktivizm ve politik İslam'dan ayrı özellikler taşır) içinde yer alan Müslüman Kardeşler; siyasi, ekonomik ve toplumsal sorunların kökeninde İslam' dan uzaklaşma olduğunu öne sürer. ${ }^{26}$

Bu doğrultuda Müslüman ulusların sorunlarını ele almak, İslam dünyasıyla temasta bulunmak ve hareketin davasını yaymak amaçlanmıştır. Müslüman Kardeşler, bu amaçların yerine getirebilmesi için kollektifliğin önemini kavramış olacak ki uluslararası aktivizmi kolaylaştırma adına coğrafi odaklı ve alt komiteler şeklinde örgütlenmeyi seçmiştir. Yedi alt komite şeklinde faaliyet gösteren bu yapının coğrafi olarak şekillenişi şu şekildedir: Sudan; Bereketli Hilal (Suriye, Lübnan, Filistin, Ürdün ve Irak); Arap Yarımadası (Suudi Arabistan, Yemen ve Körfez Ülkeleri); Kuzey Afrika (Etiyopya, Somali, Nijerya ve Senegal); Asya Müslüman ülkeleri (Endonezya, Hindistan, Seylan, İran, Afganistan ve Pakistan); Asya'daki İslami azınlıklar (Çin, Malezya ve Filipinler'deki) ve Avrupa'daki Müslümanlar (Türkiye, Rusya ve ötesi). ${ }^{27}$

25 Munson, "Islamic Mobilization," 8-12.

26 Bulut Gürpınar, "Toplumsal Hareketler ve Ortak Düşman Algısı: Suriye İhvanı ve HAMAS,” Ege Akademik Bakış 18, no. 3 (2018): 332-333.

27 Martyn Frampton, The Muslim Brotherhood and the West: A History of Enmity and Engagement (Cambridge, Massachusetts: The Belknap Press of Harvard University Press, 2018), 128. 
Müslüman Kardeşler, ilk başta Mısır'da İngiliz manda rejimine karşı duran ve İslamcılar arasında ilk siyasal sistemde değişiklik yapma amaciyla örgütlenen bir toplumsal hareket olarak, günümüze kadar 6 kıtada 72 devlette yayılma başarısı göstermiştir. Yayıldıkları ve yoğun etki bıraktıkları coğrafyalardan birisi de şüphesiz Doğu Afrika olmuştur. ${ }^{28}$

\section{Doğu Afrika'da Müslüman Kardeşlerin Etkisi}

Isaac Kfir, Doğu Afrika'da İslami hareketleri birbirinden ayırmada birtakım zorluklar bulunmasına rağmen yine de 4 gruba ayrılabileceğini öne sürer. Birincisi, siyasi temsili, inançları ve gelenekleri bağlamında ulusal tanınma için çabalamakla beraber, şiddetin amaçlarına hizmet etmeyeceğinin farkında olarak, şiddete başvurmadan ulusal siyasi sisteme entegre olmak isteyen Müslüman gruplardır. Siyasal İslamcılar olarak da adlandırılan bu gruba Kenya İslam Partisi örnek olarak gösterilebilir. İkincisi, resmi ya da gayri resmi olarak, küresel cihat ağına mensup olan ve amacı halifeliği restore etmeyi amaçlayan gruptur. Üçüncüsü, şeriatın uygulanmasını isteyen ve bu uğurda şiddet uygulamayı makul gören gruptur. Bu gurubun modus operandi anlamında yürüttüŭgu faaliyetleri çoğu zaman terörist faaliyetler olarak değerlendirmek zorlaşmaktadır. Dördüncüsü, kendi anayurtlarını farklı etnik ya da dış işgalcilerden özgürleştirmeyi isteyen, gerektiğinde cihadı olanaklı gören etno-milliyetçi İslamcılardır. ${ }^{29}$ Buna Etiyopya'nın Somali'deki askeri varlığından rahatsızlık duyanların direniş amaçlı oluşturmuş oldukları Somali'nin Yeniden Kurtuluş İttifakı (ARS) ${ }^{30}$ örnek olarak verilebilir.

İslam'ın, Doğu Afrika'daki varlığı yüzyıllar öncesine uzanmaktadır. Bölgenin İslamlaşmasında Osmanlıların, selefiliğin (sonrasında vahhabiliğin), köleliğin, ticaretin, Asya ülkelerinden Afrika'ya göçü teşvik eden Avrupalı sömürgecilerin (hatta bu Deobandi Okulu gibi farklı bir İslam geleneğinin oluşmasında) etkisi belirgindir. Kfir, Doğu Afrika'daki

Gürpınar, "Suriye İhvanı ve HAMAS,” 333-334.

29 Kfir, "Islamic Radicalism in East Africa," 830-831.

302007 Eylülünde Asmara'da İslam Mahkemeler Birliği’nin halefi olarak kurulmuştur. 2008'deki Cibuti Görüşmelerinde ARS ile Geçici Federal Hükümet arasında birlik hükümeti kurulması kararlaştırılmıştır. Bu süreçte eş-Şebab bu oluşumun dişında kalmayı seçerek, saldırılarını sürdürecektir. 
İslami aktivizmi siyasal islam, misyoner ve cihadcı şeklinde üç kulvara ayırarak ele almaktadır. Siyasal islamın siyasal partilerle, misyonerliğin tebliğ ve selefilikle, cihadcılığın ise milliyetçi, etno-milliyetçi ve küresel şekilde cereyan ettiği tespitinde bulunan Kfir, küresel cihadın hedefini halifelik, siyasal partilerin hedefinin İslam devleti oluşturma, diğerinin ise İslami devlet ya da halifelik şeklinde iki hedefi olabileceğini belirtir. ${ }^{31}$

Doğu Afrika'da son yıllarda radikalleşmenin artması; geleneksel ve Sufi tasavvufi uygulamalar karşısında Selefi ve Vahhabi ideolojilerinin güçlenmesi ve bu ideolojilerden etkilenen aşırılık yanlısı ve terörist grupların ortaya çıkmasıyla kendini göstermiştir. Bu durum kısmen sosyopolitik faktörlerin kısmen de Doğu Afrika bölgesine özgü gerekçelere dayanmaktadır. Bölge, İslam'ın farklı akımlarının etkisine açıktır. Özellikle Suudi fonları ve ideolojisi ihracının, uluslararası radikal ağların, İran'daki İslam devriminin ve Müslüman Kardeşlerin etkileri, bölgenin dişından ancak coğrafi ve kültürel yakınlığı nedeniyle Orta Doğu'nun Doğu Afrika'daki güçlü tesirini göstermektedir. ${ }^{32}$ Özellikle 2010'un sonunda başlayan Arap isyanları sonrası Suudi Arabistan öncülüğündeki koalisyon (BAE, Bahreyn ve Sisi Mısır'1), Müslüman Kardeşleri rejimleri için tehdit olarak görmüşlerdir. ${ }^{33}$

Doğu Afrika'da İslami gruplar arasındaki rekabet, geleneksel Sufi İslam ile İslam'ın Selefi ve Vahhabi yorumları arasında bir mücadele olarak kendisini gösterir. Müslüman Kardeşler de Selefiliğin siyasi ifadesinin yayılması için önemli bir rol oynamıştır. El-Benna tarafından öngörülen hedeflerin hiyerarşisini takiben bir İslami düzen (el-nizam el-İslami) oluşturulması amacı vardır: Müslüman birey, Müslüman aile, Müslüman toplum, Müslüman hükümet, Müslüman devlet ve nihayetinde halifelik inşa etmek. Bununla birlikte 1928 'de Misır'da kurulduğundan bu yana Müslüman Kardeşler, politik ortamındaki değişikliklere tepki olarak bir dizi aşamadan geçerek evrimleşmiş ve dünya çapında şubeleri olan bir örgüt halini almıştır. Müslüman Kardeşler, Doğu Afrika'da, Hasan el-Turabi'nin Sudan'daki Ulusal İslami Cephesi'nin (NIF) militan İslamcı biçiminden,

Kfir, "Islamic Radicalism in East Africa," 831-832.

Angel Rabasa, Radical Islam in East Africa (Santa Monica, CA: RAND Corporation, 2009), 39.

33 Harry Verhoeven, "The Gulf and the Horn: Changing Geographies of Security Interdependence and Competing Visions of Regional Order," Civil Wars 20, no. 3 (2018): 348 . 
Somali'deki görünüşte modernist ve şiddetsiz el-Islah hareketine kadar farklı biçimler almıştır. 1940'larda Sudanlı öğrenciler, Kahire'de kendi Müslüman Kardeşler şubesini kurmuşlar ve daha sonra Misır hareketi tarafından Sudan'da üye toplamaya gönderilmişlerdir. Bu sayede Sudan şubesi, resmi olarak 1954 y1lında kurulmuştur. ${ }^{34}$

Sudanlı üyeler, Sudan'da İngiliz yönetimi hakimken Mısır'la birleşme yanlısı olmakla birlikte, Abdünnasır rejimin baskıları nedeniyle bu düşünceden vazgeçmişler ve bağımsızlık yanlısı tutum takınmışlardır. Bağımsızlık sonrasında 1964'te kendisini İslam Şartı Cephesi (ICF) olarak revize etmişler ve İslam Şeriat yasası tarafından yönetilen bir Sudan için lobi yapmaya başlamışlardır. ${ }^{35} \mathrm{Bu}$ dönemde Sudan Müslüman Kardeşlerinin yeniden örgütlenmesinde Hasan Abdullah el-Turabi'nin önemli pay1 vardır. Yasal olarak faaliyet gösteren tek siyasi parti olan İslamcılar, Sudan toplumu üzerindeki etkilerini genişletebilmişlerdir. Ayrıca bu dönemde, İslami bankacılıktan yatırıma, giyimden ticarete kadar farklı sektörlerde etkinlik kurmuşlardır. ${ }^{36}$

Bununla birlikte 1969'daki Numeyri darbesi sonras1 Sudan Müslüman Kardeşler üyelerinin büyük bölümü tutuklanmış ve bir kısmı idam edilmiştir. Ancak Numeyri, sol eğilimli bir darbe teşebbüsünün ardından Müslüman Kardeşlerin desteğine ihtiyaç duymuş ve onlarla 1970'lerde iyi bir ilişki kurmuştur. Hatta 1973’teki yeni anayasada, kanunların dine uygunluğunun tespiti amaciyla oluşturulan konseyin başkanlığına Hasan elTurabi atanmıştır. Sudan'da Müslüman Kardeşler bu süreçte güçlenmişler ve isimlerini Ulusal İslam Cephesi (NIF) olarak değiştirmişlerdir. Sudan Müslüman Kardeşleri, Numeyri sonrasında siyasal parti olarak seçimlere girmiş ve el-Turabi değişik hükümetlerde Adalet Bakanlığı gibi üst düzey görevler üstlenmiştir. Ancak 1989'da Sudan'da darbe ile yönetimi ele geçiren Hasan el-Beşir ile ilişkileri istikrarsız olmuştur. 1999'da Beşir'in cumhurbaşkanı olarak yeniden seçilmesini engelleme girişimiyle araları iyice bozulmuş ve bu olay sonrası hareketin başından da ayrılmıştır. ${ }^{37}$

\footnotetext{
34 Rabasa, Radical Islam in East Africa, 40.

35 Ülger, "Müslüman Kardeşler Teşkilatının İdeolojisi," 144.

36 Solomon, "Political Islam: An African Perspective," 96.

37 Ülger, "Müslüman Kardeşler Teşkilatının İdeolojisi," 144-145; M.A. Mohamed Salih, "Transnational Islamist (Jihadist) Movements and Inter-State Conflicts," Nordic Africa Institute: Policy Notes (2011): 1.
} 
Turabi'nin etkisinde ve gölgesinde kalan Sudan'daki Müslüman Kardeşler, Yemen'de (Yemen el-Islah ismi ile bilinir) siyasi olarak güçlenmişlerdir. Yine sslah ismini kullanan Somali'deki el-Islah ise ülkenin içinde bulunduğu iç savaş nedeniyle Somali'den kaçanların oluşturdukları, 1lımlı ve daha çok sosyal hizmet sağlayıcı yönleriyle hem Somali'de hem de bölgede öne çıkmıştır. ${ }^{38}$

\section{Somali'de Dini Gruplar}

Afrika Boynuzu'na İslam 1400 yıl önce Arap Yarımadasından (özellikle Umman ve Yemen'den) ticaret ve göçle ulaşmıştır. Somali'de ilk Dir klanı tarafindan benimsenen İslam, daha sonra tüm ülke geneline yayılmıştır. Günümüzde nüfusun tamamına yakını Sünni Müslüman ve Şafii mezhebindendir. ${ }^{39}$

Somali'de tüm Müslümanları temsilen bir büyük kadı ve önemli yerleşim yerlerinde kadıların idaresinde İslam mahkemeleri bulunurken, 1970'te bu mahkemelerin sayısı 47'ye ulaşmıştır. Somali'nin İslamlaşmasında Sufi (tasavvuf) tarikatların büyük rolü vardır. Bunlardan ilki, kökleri 15. yüzyıla kadar uzanan Kadiriyye'dir. Bu, Şeyh Abdurrahman Zeylai tarafindan kuzey Somali'de etkin olmuştur. İkincisi, Ahmed bin İdris'in liderliğini yaptığı İdrisiyye (Ahmediyye) tarikatıdır. Bunun 19. yüzyılda reformist türevi ise Salihiyye tarikatıdır ve üçüncü tarikat olarak kabul görmektedir. Bu tarikat, Mekke'den Somali'ye göç eden Muhammed b. Salih er-Reşidi tarafından kurulmuş, Şeyh Ali May Durogba aracılı̆̆ıyla Marka ve Şebelle bölgesinde etkili olmuştur. Dahası ülkedeki milli direniş hareketinin lideri Muhammed bin Abdullah Hasan Serbera'da, Seyyid Muhammed ed-Denderavi ise Somaliland'da bu tarikatın temsilcileri olmuşlardır. Dördüncüsü, Makdişu ve Marka'da yerleşik Makalla Arapları'nın benimsediği Rifaiyye'dir. ${ }^{40}$

38 Stig Jarle Hansen ve Atle Mesøy, "The Muslim Brotherhood in the Wider Horn of Africa," NIBR Report 33 (2009): 4.

39 Georg-Sebastian Holzer, "Political Islam in Somalia: A fertile Ground for Radical Islamic Groups?," Geopolitics of the Middle East 1, no. 1 (2008): 23.

40 Ahmet Kavas, "Somali," Türkiye Diyanet Vakfi İslâm Ansiklopedisi 37 (İstanbul: TDV Yayınlar1, 2009), 375; David Last ve Anthony Seaboyer, "Clan and Islamic Identities in Somali Society,” Defence R\&D Canada Report (2011): 81. 
Geleneksel İslami okulların ve ulemanın, İtalyan Somaliland'ındaki sömürge yönetimine yönelik siyasi muhalefeti dışında öne çıkmadıkları görülmektedir. Bu durumun, tarihsel süreçte şeriatın Somali'de yerleşik olmaması ve büyük ölçüde kırsalda bir yaşam tarzının benimsenmiş olmasından ileri geldiği söylenebilir. Bu aynı zamanda dini reçetelerden ziyade geleneksel yasaların (xeer) işletildiğinin göstergesidir. ${ }^{41}$ Sömürge öncesi dönemlerde ve kısmen sömürge sonrasında ülkede klan büyükleri ve dini liderler olarak iki ayrı otorite, bireysel ve toplumsal ilişkilerin yürütülmesinde etkili olmuştur. ${ }^{42}$

Bazı sufi emirleri sömürgecilik karşı1tı direnişte aktif rol oynasalar da modern bir siyasal bilincin ortaya çıkması ancak 1960'larda el-Ahli' ${ }^{43}$ ve Vahdet eş-Şebab'ın oluşmasıyla ivme kazanmaya başlamıştır. Her ikisi de yeni, bağımsız ve modern bir Somali devleti bağlamında İslami ilkeleri uygulamayı amaçlamış ve Mısır'ın Müslüman Kardeşlerinden esinlenmişlerdir. ${ }^{44}$

Bununla birlikte 1969'daki darbe ile iktidara gelen Muhammed Ziad Barre, 1970'te resmi olarak "bilimsel sosyalizmi”" ilan etmiş ve ülkedeki İslami gruplar da dahil olmak üzere tüm devlet dışı örgütleri yasaklamıştır. ${ }^{45}$ Binlerce İslam alimi yurtdışında örgütlü bir hareket başlatmak amacıyla Suudi Arabistan, Mısır ve Sudan gibi ülkelere kaçmış ya da yer altında gizlenmek durumunda kalmıştır. Bu durum, daha önce birleşmiş bir görüntü çizen Somali Müslümanları arasında ideolojik bölünmeye yol açmıştır. Öyle ki bunlar 1970'lerin sonlarında Somali'ye döndüklerinde yanlarında bölücü ideolojiyi ve İslam'ın farklı yorumlarını getirmişlerdir. ${ }^{46}$

41 Last ve Seaboyer, "Clan and Islamic Identities in Somali Society," 48.

42 Shaul Shay, Somalia Between Jihad and Restoration (USA: Transaction Publishers, 2008), 37.

43 Jama'at al-Ahl al-Islaami olarak da bilinir ve 1969 'da Barre iktidara gelince dağılmak zorunda kalmıştır. Vahdet eş-Şebab üyeleri ise ülke dışına çıkmak ya da yer altına gizlenmek zorunda kalmıştır. (Anouar Boukhars, "Understanding Somali Islamism," Son erişim tarihi: 27 Şubat 2021, https://jamestown.org/program/understandingsomaliislamism/)

44 Ruan van der Walt ve Hussein Solomon, "Histories and Spaces of Terrorism in Africa: The Post-9/11 Strategic Challenge of Somalia's al Shabab," Afro Eurasian Studies Journal 3, no. 1 (2014): 86.

45 Holzer, "Political Islam in Somalia," 24.

46 Abdurahman M. Abdullahi, Meeting Summary: Islamism and Politics in Somalia. Londra: Chatham House (2012): 2-3. 
Zira sürgündeki Somalililer'den bazıları, Müslüman Kardeşlerle uyumlu hareket ederek siyasi eylemden yana tutum takınmışlardır. Diğerleri ise selefi-vahhabi fikirlerden ve Afganistan'daki Sovyet karşıtı cihatçılardan etkilenmişlerdir. Bu durumun olumlu yönü ise Somalili İslamcı hareketin gelişmesi adına katkı verici olmasıdır. ${ }^{47}$

Bu süreçte Somali'de siyasal İslamın gelişmesini teşvik eden başka gelişmeler de yaşanmıştır. Örneğin Somali'nin, 1974'te Etiyopya'nın Ogaden bölgesini geri alabilmesi için diplomatik destek ve uluslararası yardım elde etmek için Arap Birliği'ne üye olması sayesinde çok sayıda Somalili öğrenci el-Ezher ve Suudi Arabistan gibi yerlerde eğitim alabilmişlerdir. Somali ordusunun 1977-78 Ogaden Savaşı'nda Etiyopya'ya yenilmesi ve 1979'daki İran İslam devrimi gibi gelişmeler de bu eğilimi değiştirmemiştir. ${ }^{48}$ Öyle ki 1980'lerde Somali İslamcı hareketi önemli ölçüde büyümüştür. 1991'de Barre rejiminin devrilmesi ise bu örgütlere daha fazla alan açmıştır. Somali'de benzersiz bir İslami rejim arzusunda olan bu hareketler arasında temel farklılıklar, doktrinel (gelenekçiler, reformistler, modernistler, selefiler, cihatçılar gibi), liderlik, baskın klan ilişkisi ve sektörel çıkarların değişik olmasından ileri gelmiştir. ${ }^{49}$

Somali'deki dini gruplar şu şekilde özetlenebilir: ${ }^{50}$

1- Cihâdî İslamcılık (Jihadi Islamism): İslamcıllğın siyasi ve misyoner akımlarından farklı olarak cihat eylemcileri, şiddete ve silahlı direnişe kendilerini adamışlardır.

a) Tekfir ve Hicret (Al Takfir Wal Hijra)

b) El-İttihad el-İslamiye (AIAI/Al-Itihad Al-Islamiya/Unity of Islam) (Aşağıdaki iki koldan oluşan bu grup 1982-1984 yılları arasında birleşerek bu ismi almıştır.)

b.1) İslam Camiası/Cemaat-i İslamiye (Al Jama'a al Islamiya) (Mogadişu'da ve Şeyh Dahir Indhabour, Abdullahi Ali Haşi, Şeyh Abdulkabir Ga'amey liderliğindeki selefi grup)

b.2) İslami Gençlik Birliği/Vahdet eş-Şebab el-İslamiye (Wahadat al Shabaab al Islamiya) (Kuzey Somali'de, Şeyh Ali Varsame

47 van der Walt ve Solomon, "Histories and Spaces of Terrorism in Africa," 86.

48 Holzer, "Political Islam in Somalia," 25.

49 Shay, Somalia Between Jihad and Restoration, 37.

50 A.g.e., 38-47. 
liderliğinde ve Müslüman Kardeşlerden esinlenen vahhabi grup)

2- Misyoner İslamizm

a) Selefiyye Cedide/Yeni Selefiler (Salafiyya Jadiida)

b) Cemaat el-Tebliğ (Jama'at al-Tabligh)

c) El-Ensar el-Sünnet (Al-Ansar al-Sunna)

3- Siyasi İslamc1lık (Political Islamism)

a) Somali'deki İslam Ümmeti (Majma Ulimadda Islamika ee Somaliya)

b) Ehli Sünnet vel-Cemaat (Ahlu Sunna wal Jama'a)

c) El-Islah Hareketi (Harakat Al-Islah)

Somali'de dini gruplar denildiğinde El-İttihad el-İslamiye (AIAI) ve el-Islah'ın önemli bir yeri vardır. AIAI kuruluş döneminde Müslüman Kardeşlerden esinlenmiştir. Ancak sonraki süreçte dönüşüm yaşamıştır. Ayrıca AIAI içinden gelen selefi-vahhabi ${ }^{51}$ eş-Şebab ${ }^{52}$ (Gençlik), son 15 yıldır ismini ülke içinde ve dışında gerçekleştirmiş olduğu saldırılarla duyurmuştur. Siyasi islamcılık içinde kategorileştirilen el-Islah ise hem 1lımlı olması hem de Müslüman Kardeşlerle ilişkisi bağlamında öne çıkmaktadır.

Eş-Şebab'ın kuruluşu, 1994'te Mogadişu'da kurulan İslam Mahkemeler Birliği’ne (IMI /Ittihad al-Mahakim al-Islamiya) kadar geri götürülebilse ${ }^{53}$ de 2004'te IMI'nın askeri kolu olarak ortaya çıktığı kabul edilmektedir.

51 Burada selefi-vahhabi denilirken, Selefiliğin katı biçimi olan Vahhabilik (Vehhabilik) kastedilmektedir. Selefiyye Ehl-i Sünnet içinde yer alır. Selefiliğin pasif biçimi, mezhepleri reddeden, silahlı eylemleri onaylamayan ve Kur'an ve sünnete dönmeyi savunan entelektüel selefi hareketi içerir. Selefiliğin katı biçimi olan Vahhabilik ise; 19. yüzy1lda vücut bulan dini-politik bir hareketi içerir. Bu genellikle silahlı bir eylemi politik bir amaç için araç yapabilen bir harekettir. Bunlara göre; şirk ve küfür, dinden çıkarıcı eylemlerdir. (Hilmi Demir, “Aklı Karışıklar İçin Selefilik ve Sünnilik Rehberi," Son erişim tarihi: 16 Şubat 2021, https://www.21yyte.org/tr/merkezler/aklikarisiklaricin-selefilik-ve-sunnilik-rehberi).

52 Eş-Şebab ayrıca şu adlarla da bilinir: El-Şebab, el-Şebab el-Islam, el-Şebab el-Cihad, Hareket el-şebab el-Mücahidin, Hizbul Şebab, Mücahidin Gençlik Hareketi, Genç Mücahit Hareketi, Genç Kanat (Australian National Security, "Al-Shabaab," Son erişim tarihi: 2 Haziran 2020, https://www.nationalsecurity.gov.au/).

53 Dirk Baehr, "The Somali Shabaab Militias and Their Jihadist Networks in the West," KAS International Reports 8, (2011): 23. 
Barre rejimi döneminde albay olarak görev yapmış ve 1970'lerde Etiyopya'ya karşı savaşmış Hasan Dahir Aveys, örgütün kurucu lideri olarak bilinmektedir. Geçici federal hükümeti devirerek ülkenin tamamını kontrol etmeyi ve Etiyopya ve Kenya gibi Somalililerin yaşadığı yerleri de içerecek şekilde geniş bir İslam devleti kurmayı amaçlamaktadır. EşŞebab'ın tarihsel kökleri, el-İttihad el-İslamiye'ye (AIAI) kadar geri gider. AIAI, 1982-84 yılları arasında İslami Gençlik Birliği ve İslam Camiası'nın birleşmesiyle oluşmuştur. Barre rejimini (1969-1991) devirmeyi, ülkedeki yoksulluk ve yolsuzluğu gidermeyi, Batı etkisini ortadan kaldırmayı ve bir İslam devleti kurmayı amaçlayan AIAI'nın kurucusu olarak Şeyh Ali Varsame bilinmektedir. ${ }^{54}$ AIAI, kendisini siyasi ve askeri bir hareket olarak görmektedir. Sudan'daki el-Turabi'nin Milli İslami Cephesi gibi, AIAI'nın liderleri de Mısır Kardeşlerinden etkilenmişler ve bazıları Mekke, Medine ve Kahire'de eğitim görmüşlerdir. Somali'deki klanlar üzerinde yapısal bir düzen oluşturamayan AIAI, Afrika Boynuzu'nda siyasi İslamın ve cihatçı örgütlenmelerin ortaya çıkmasında rol oynamıştır. ${ }^{55}$

Barre rejimi sonrasında AIAI, siyasi parti olarak faaliyet yürüteceğini duyurmuş ve ülkede şirketler, okullar, yetimhaneler açarak öncelikli olarak üyelerinin yararına sunmuştur. Hasan Dahir Aveys'in AIAI'ya 1993'te katılması ile örgüt silahlı mücadelelerini artırmış, Ogaden, Dirre Dawa ve Addis Ababa'da saldırılar düzenlemiş ancak 1990'ların sonunda zayıflamıştır. ${ }^{56}$ Bunun üzerine birkaç taktik izlemiştir. İlk olarak, Somali'nin henüz İslami egemenliğe hazır olmadığını anlamış ve klanların İslam eğitimine önem vererek Somali toplumunu eğitmek için uzun vadeli bir strateji gereksinimi duymuştur. İkincisi, AIAI üyeleri hedef alınmaktan kaçınmak için kendilerini yerel Somali topluluklarıyla bütünleştirmeyi seçmiştir. Ayrıca hücrelerini stratejik ve izole kırsal alanlara yerleştirmiştir. Üçüncüsü, güçlü bir taban oluşturmak için ticarete yönelme ve iş insanlarını üye yapma eğilimine girmiştir. Son olarak, "Turabi" stratejisi olarak bilinen stratejiyi benimseyerek yerel yönetimlerin kilit bölümleri

54 Abdurrahim Sıradağ, "Sahra Altı Afrıkası'nda Terörist Grupların Yükselişi: Boko Haram ve Eş-Şebab," SETA 125 (Mayıs 2015): 16-17.

55 Annette Weber, "Eş-Şebab: Allahsız Gençlik," içinde Afrika'da Cihatçılık: Yerel Sebepler, Bölgesel Büyüme, Uluslararası İşbirliği, ed. Guido Steinberg ve Annette Weber, ORDAF Rapor 15 (2016): 24.

56 Terje Østebø, "Islamism in the Horn of Africa: Ideology, Actors, and Objectives," International Law and Policy Institute (ILPI) Report (2010): 24. 
üzerinde kontrolü denemiştir. Yani yönetimin doğrudan kontrolünü talep etmeden, yavaş yavaş bir sivil hükümeti aşamalı olarak ortadan kaldırmayı ve siyaseti dolaylı olarak kontrol etmeyi planlamıştır. ${ }^{57}$

Buna rağmen 21. yüzyılın başında AIAI çözülmeye başlamıştır. Üyelerinin bir kısmı el-Kaide ile bağlantılarından dolayı uluslararası baskılara maruz kalırken, bir kısmı canlanmakta olan şeriat mahkemelerine katılmış, diğerleri ise radikal kalmayı seçerek daha sonra kurulacak olan eş-Şebab'ın alt zeminini oluşturmaya başlamışlardır. ${ }^{58}$ Geçici Ulusal Hükümet' in ${ }^{59}$ görev süresinin 2004'te sona ermesi ve bu girişimin başarısızlığ Dahir Aveys ve Şeyh Şerif Ahmed liderliğinde İslami mahkemelerin canlanması için bir alan açmıştır. ${ }^{60}$ Bazı AIAI faaliyetlerini de bünyesinde barındıran ve ülkedeki şeriat mahkemelerin birleşimi olan IMI, 2006'da Mogadişu ve ülkenin orta ve güney kesimlerini kontrol etmeyi başarmıştır. Hatta IMI'nın artan gücüne karşı savaş ağaları, ABD tarafından desteklenen Terörizm ve Barışın Restorasyonu İttifakı (ATRP) altında örgütlenmiş ve IMI'ya karşı bir saldırı başlatmışlar ancak başarılı olamamışlardır. Bu sefer 2006 Aralık ayının sonlarında Etiyopyalı kuvvetler müdahale etmişler ve IMI milislerini yenip iktidardan uzaklaştırmışlardır. ${ }^{61}$

IMI, 2007'de 1lımlılar ve aşırılar olmak üzere ikiye ayrilırken, 1lımlıları 2009'da Geçici Federal Hükümete katılan Şeyh Şerif Ahmed liderliğindeki grup oluştururken, aşırıları Hasan Dahir Aveys öncülüğündeki İslam Partisi olan Hizb-ül İslam ve eş-Şebab oluşturmuştur. ${ }^{62} 2008$ 'deki Cibuti süreci sonras1 ve yeni Geçici Federal Hükümet Başkanı olarak IMI'nın eski lideri Şeyh Şerif Şeyh Ahmed'in seçilmesi (2009 Ocak-2012 Ağustos), selefi grupların daha güçlü muhalefetini beraberinde getirmiştir. ${ }^{63}$

57 van der Walt ve Solomon, "Histories and Spaces of Terrorism in Africa," 87.

58 Matthew Cavedon, "Men of the Spear and Men of God: Islamism's Contributions to The New Somali State," Emory International Law Review 28, no.1 (2014): 486.

59 Geçici Ulusal Hükümet 2000-2004, Geçici Federal Hükümet 2004-2012, 2012'den günümüze Somali Federal Hükümeti işlemektedir. 2012 Temmuzunda ülkede 20 y1l sonra ilk defa parlamento toplanmış ve merkezi hükümet kurulabilmiştir.

60 Holzer, "Political Islam in Somalia," 31-32.

${ }_{61}$ Østebø, "Islamism in the Horn of Africa: Ideology, Actors, and Objectives," 25.

62 Siradağ, "Boko Haram ve Eş-Şebab," 17.

63 Roland Marchal ve Zakaria M. Sheikh, "Salafism in Somalia: Coping with Coercion, Civil War and its Own Contradictions," Islamic Africa 6, no. 1-2 (2015):138-139. 
Eş-Şebab'ın özellikle Somali içinde etkinlik kurmasında Etiyopya'nın Somali'ye yönelik askeri müdahalesinin (2006 Aralık ayından 2009 Ocak ayına) önemli bir yeri vardır. Bu saldırıya karşı mücadele eden bir örgüt olması, Somali'de milliyetçi kanadın desteğini çekmiş, siyasi ve askeri gücünü artırmıştır. Bu süreçte eş-Şebab; Etiyopya'yı ve Geçici Federal Hükümeti suçlayan Somali diasporasının da desteğini kazanmıştır. EşŞebab'ın hedefleri arasında şunlar vardır: Ülkenin İslamlaşmasında önemli rolü olan sufi tarikatlarla mücadele etmek, Somali halkını kendi ideolojik (selefi-vahhabi) yapısıyla uyumlu hale getirmek ve Boko Haram gibi cihad kavramını radikal bir içeriğe indirgeyerek askeri mücadele yürütmek. Somali'deki sömürgeci mirasın olumsuz etkisiyle ilişkili olarak Etiyopya, Kenya ve Cibuti'de Somali nüfusunun birliğinin dağılmış olması, sosyoekonomik problemler, devletin temel işlevlerinde ve siyasal sisteminde kusurlar, merkezi hükümetin uzun süre kurulamaması, ülke bütünlügünde sıkıntılar (Somaliland'ın 1991'de bağımsızlı̆̆ını, 1998'de Puntland'ın özerkliğini ilan etmesi, Kenya destekli Jubaland sorunu), Somali'ye yönelik dış müdahaleler, eş-Şebab'ın ülkede güçlenmesi ve zemin kazanmasında etkili olmuştur. ${ }^{64}$

2010 yılında el-Kaide'ye katıldığını açıklayan eş-Şebab, güçlü bir bölgesel strateji izleyerek Doğu Afrika'da daha etkili terör faaliyetleri yürütmeye başlamıştır. En önemli saldırı alanı Somali olan eş-Şebab, bu doğrultuda Puntland, Somaliland ve Federal Hükümet başta olmak üzere rakip olarak gördüklerine saldırılar düzenlemektedir. Örneğin, 2010 Martında Hizbü’1 İslam komutanı Ali Bare'yi öldürerek Hizbu'l İslam'ın kendilerine katılmasını sağlamıştır. Ayrıca örgüt, Uganda, Kenya, Etiyopya ve Cibuti gibi bölge ülkelerinde de saldırılar yapmaktadır. ${ }^{65}$

\section{El-Islah}

El-Islah ya da Harekat el-Islah "reform, iyileştirme, uzlaşma ve düzeltme" anlamına gelmektedir. ${ }^{66}$ Müslüman Kardeşlerin Somali şubesi olarak

Sıradağ, "Boko Haram ve Eş-Şebab," 17-18.

A.g.e., 21-23.

66 Abdurahman M. Abdullahi, "The Islah Movement: Islamic Moderation in War-torn Somalia," Son erişim tarihi: 27 Şubat 2021, https://www.hiiraan.com/oct2008/ISLAH. pdf, 8. 
görülebilen el-Islah, 11 Temmuz 1978'de Kardeşler üyesi Şeyh Muhammed Garyare tarafindan Riyad'da (Suudi Arabistan'da) kurulmuştur. Ayrıca Dr. Ali Şeyh Ahmed, Dr. Ibrahim Dusuqi de kurucu isimler arasındadır. Bunlar küresel kardeşlik hareketinin ayrılmaz parçalarıdır. Yakın dönemde öne çıkan liderleri olarak Ali Bashi Ömer Rooraaye (Başkan), Abdurahman M. Abdullahi (İcra Kurulu üyesi), Hassan Şeyh Mahmud (Somali Eski Başkanı ve Barış ve Kalkınma Partisi/PDP Başkanı) sayılabilir. ${ }^{67}$ Örgütte ayrıca Dr. Ali Şeyh (Mogadişu Üniversitesi Rektörü) başkanlık, Abdirahman Badiyo başkan yardımcılığı ve Dr. Ibrahim Dusuqi genel sekreterlik görevinde bulunmuştur. ${ }^{68}$ Örgüt liderleri arasında İslami kimliği ve toplumsal dönüşümü savunup iktidar peşinde koşulmasına karşı çıkanlar (Şeyh Garyare) ile siyasette de yer almak isteyenler (Ali ve Badiyo) olmak üzere farklı görüşler yer almıştır. ${ }^{69}$

El-Islah'ın yüksek kurul üyeleri beş yıllığına şura meclisi tarafindan seçilirler ve görevleri iki dönemle sınırlıdır. ${ }^{70}$ Örgütte Hawiye klanının ağırlıklı olduğu eleştirilerine el-Islah liderleri belli ilkelere göre üye seçiminin olduğu cevabını vermişlerdir. ${ }^{71}$ El-Islah ilk dönemlerinde daha çok güvene dayalı ve klan temelli üye kazanımında bulunmuştur. $\mathrm{Bu}$ özellikle Barre rejimi döneminde gereklilik duyulan bir unsur olmuştur. Ülke dışındaki Somalili öğrenciler arasında aktif olan örgüt ayrıca ulema (Şeyh Nur Barud, Şeyh Hassan Dahie örgüte dahil edilmiş), doktor, mühendis, subaylardan üye alımında bulunarak bu entelektüel elit kesimin toplumu daha hızlı dönüştürebileceğine inanmıştır. ${ }^{72}$

Sufi olmayan en büyük kuruluşlardan birisi olan el-Islah, 1990'lar boyunca, başta ZamZam vakfı (1992) ve Tadamun vakfı (1992) olmak üzere birçok prestijli proje başlatmıştır. 1990'larda enerjisinin çoğunu insani faaliyetlere (özellikle kuzey Somali’ye) ve temel sosyal hizmetlerin

67 Counter Extremism Project, "Muslim Brotherhood in Somalia," Son erişim tarihi: 4 Haziran 2020, https://www.counterextremism.com/content/muslim-brotherhoodsomalia; Hansen ve Mesøy, "The Muslim Brotherhood in the Wider Horn of Africa," 38.

68 “Somalia's Islamists," International Crisis Group Africa, Report no. 100 (2005): 13.

69 Hassan M. Abukar, "Turmoil in Al-Islah, Somalia's Muslim Brotherhood," Somali Observer, Son erişim tarihi: 4 Haziran 2020, http://somalicolumn.blogspot. com/2012/07/turmoil-in-al-islah-somalias-muslim.html

70 Shay, Somalia Between Jihad and Restoration, 38.

71 "Somalia's Islamists," 14.

72 Hansen ve Mesøy, "The Muslim Brotherhood in the Wider Horn of Africa," 40. 
restorasyonuna adamış ve eğitimde (Arapça okulları gibi) önemli adımlar atmıştır. Ayrıca tıbbi programların ve ticari girişimlerin yanı sıra barış konferanslarına da katkı vermiştir. Örneğin Arta Barış Konferansı'ndaki rolü buna örnek olarak verilebilir. Çok partili demokrasi, basın özgürlügü, serbest seçimler el-Islah'ın üzerinde durduğu unsurlardır. Farklı anlayışlara sahip Müslümanları kabul ederek çeşitlilikte birliğe inanması, demokrasiyi ve kadınların siyasete katılımını desteklemesi özellikle diğer grupların tepkisini çekmiştir. ${ }^{73}$

El-Islah'ın eski başkanı Dr. Ali Şeyh Ahmed'e göre; “Islah, Somali'de İslami 1lımlılığın ilkelerine ve metodolojisine bağlı, barışçıl bir İslami harekettir". ${ }^{74}$ Yine el-Islah üyesi Abdullahi'ye göre; "Islah ne Batı karşıtı bir harekettir ne de İslami değerlere aykırı olan Batı kültür kalıplarını taklit eder. Bunun yerine, Somali halkı için sosyal ve kültürel gerçeklikler temelinde hareket eden, olgun ve ileriye dönük Somali yanlısı yerli bir reformist harekettir." 75

El-Islah, toplumdaki İslami değerlerin canlandırılması, Somali kültürünün, devlet yasalarının ve politikalarının İslami yasal çerçeve ve değerlerle uyumlaştırılmasını teşvik etmek amacıyla kurulmuştur. ${ }^{76}$ Diğer bir deyişle amacı, Somali'de şeriat yasalarına dayalı İslami bir devlet kurmak ve Somali toplumunda İslami ilkeleri teşvik etmektir. Bunu, Mısır Müslüman Kardeşleri modelini izleyerek gerçekleştirilebileceğine inanmaktadır. ${ }^{77}$ Bu nedenledir ki el-Islah'ın Mısır Kardeşleri ile güçlü ve yakın bir ilişkisi bulunmaktadır. El-Islah'ın, el-Turabi'nin Afrika'da pan-İslami bir örgüt oluşturma girişimlerine katılmayı reddetmesi, el-Islah'ın Mısır Kardeşleri arasındaki popülaritesini artırdığı gibi Müslüman Kardeşlerin uluslararası yapısına resmen kabul edilmesine de katkıda bulunmuştur. Aynı yı1 Uluslararası Şura Kardeşler Konseyi'nde yer alan ilk Sahra-altı Kardeşlik örgütü olmuştur. El-Islah ayrıca, kendisini saf bir Somali örgütü olarak görmemiş ve diğer Afrika Boynuzu ülkelerinde faaliyetlerde bulunmuştur.

73 Hansen ve Mesøy, "The Muslim Brotherhood in the Wider Horn of Africa," 49-51; Cavedon, "Islamism's Contributions to The New Somali State," 483.

74 Abdullahi, "The Islah Movement," 2.

75 A.g.e., 8-9.

76 Abdullahi, "Meeting Summary," 3; Abdullahi, "The Islah Movement," 30.

77 Evie Browne ve Jonathan Fisher, Key Actors Mapping: Somalia (Birmingham, UK: GSDRC, University of Birmingham, 2013), 13. 
Günümüzde el-Islah'ın Kenya, Etiyopya ve Cibuti'de faaliyetleri bulunmaktadır. Özellikle bu ülkelerdeki Somalililer arasında aktiftir. ${ }^{78}$

El-Islah, diktatörlük (1969-1991) ve iç savaş (1991-2008) döneminde barışçıl İslami reformları teşvik eden, modern ve 1lımlı bir yaklaşım benimsemiştir. İlk dönem kuruluş, zulüm ve hayatta kalma zorluklarıyla mücadele etmiştir. İkinci dönemde eğitimli elitlere odaklanarak topluma açılma, geleneksel İslam alimlerine, milliyetçi hareketlere saygı gösterme ve onlarla işbirliği yapma, tartışmalı dini konulardan uzak durarak şiddet ve aşırıcılığı reddetme, ulusal devlet kurumlarının restorasyonu, sivil toplum örgütlerinin, demokrasinin ve kadın haklarının teşviki ve insan haklarının korunması gibi politikalar izlemiştir. Ayrıca örgütsel yapısının esnekliği ve iç demokratik uygulamalar sayesinde 11 mlı İslami hareket çizgisinde ilerlemiştir. $^{79}$

Somali'de neredeyse her örgütlü siyasi hareket kendisini İslami terimlerle tanımlamaktadır. Bu, 1970'ler ve 1980'lerde Barre rejiminin seküler "bilimsel sosyalizminden" önemli bir değişimdir. ${ }^{80}$ Bununla birlikte 1978'den günümüze Somali'de modern merkezi devlet ile çelişen ideolojiler bir başka deyişle devletle toplum arasında süre gelen bir karşıtlık vardır. Bunda İngiliz, Fransız ve İtalyan sömürgeci mirasın, coğrafyanın, soğuk savaşın, uluslararası terörizmin, deniz haydutluğunun ve devlet içi istikrarsızlığın etkileri elbette hissedilmektedir. Ancak söz konusu karşıtlığın özellikle üç çatışma alanından beslendiği söylenebilir. Birincisi, modernite ile gelenek arasındaki çatışmadır. İkincisi, İslamcılık, milliyetçilik ve klanizm arasındaki çatışmadır. Üçüncüsü, tasavvuf(sufilik), selefilik ve Müslüman Kardeşler başta olmak üzere İslam toplumdaki farklı akımlar arasındaki çatışmadır. Aşırılık (extremist) yanlısı hareketler özellikle 1991'de devletin çöküşü ile etkinlik kazanmıştır. Bu dönemde AIAI bünyesinde el-Kaide katılımlı, İslami ve milliyetçi gündemle hareket eden bir silahlı grup oluşturulmuştur. Ancak AIAI silahlı mücadeleyi terk ettiğinde 2003 'ten sonra alan eş-Şebab'a kalmıştır. ${ }^{81}$

\footnotetext{
78 Hansen ve Mesøy, "The Muslim Brotherhood in the Wider Horn of Africa," 39,42.

79 Abdullahi, "Meeting Summary," 3; Abdullahi, "The Islah Movement," 30.

80 Alex de Waal, Somalia Synthesis Paper (Londra: LSE Conflict Research Programme, 2017), 15.

81 Abdullahi, "Meeting Summary," 3.
} 
EI-Islah'ın, kökleri Müslüman Kardeşlere uzanan gerek eş-Şebab gerekse de AIAI'dan gelinen aşamada oldukça farklı olduğu görülmektedir. Örneğin, 1989'da Barre rejiminin sonuna gelindiğini anlayan el-Islah, örgütlenme yönünden zayıflıklarını gördügü için AIAI ile işbirliği yapmaya yönelmiştir. Ancak çok geçmeden iki örgüt arasında önemli farklılıklar bulunduğu anlaşılmıştır. AIAI; el-Turabi'nin Sudan'ına daha yakın bir çizgide yer almasının yanında daha parçalı örgüt yapısını ve şiddet yanlısı güçlü bir selefi-vahhabi unsuru barındırmıştır. Ayrıca AIAI lideri Şeyh Ali Varsame gibi birkaç eski el-Islah üyesinin AIAI'ya geçmesi, aralarında önemli sorun oluşturmuştur. Bütün bunlar Kardeşlik unsurlarıyla eski bağlara sahip AIAI ile el-Islah arasında işbirliğini engellemiş ve ideolojik farklılıklar ağır basmıştır. ${ }^{82}$

El-Islah'ın liderleri bu yüzden AIAI'nın beslendiği selefi-vahhabiliği "aşırıcılık, içe dönük bir inanç sistemi", bunun üyelerini de "münhasırlık ve mutlakiyetçiliğe inanan aşırılık yanlıları" olarak görme eğilimindedirler. ${ }^{83}$ Buna karşın pragmatik bir siyasi İslam anlayışını benimseyen Müslüman Kardeşler grubu olan e-Islah; İslamcı militan grup AIAI (devlet) ve elKaide üyesi eş-Şebab (halifelik) gibi zorla İslami hakimiyet kurmak isteyen selefi-vahhabi çizgiden ayrı bir noktadır. Bu anlamda bir İslam devleti kurma çabalarında şiddetten kaçındıkları gibi tekfiri de İslami bulmadıkları öne sürülmektedir. Ancak bu el-Islah'ın tamamen şiddetten uzak olduğu anlamına gelmez. Örneğin, el-Islah'ın alt kanadı olan Damul Cedid, Etiyopya'nın Somali’ye askeri müdahalesi esnasında şiddeti açıça benimsemiş ve IMI ile birlikte mücadele etmiştir. Dahası bu Damul Cedid, 2006'da Etiyopya'nın Somali işgaline karşı el-Islah içindeki bazı üyelerin silahlanmasıyla kurulmuştur. Bu oluşum aynı zamanda söz konusu işgale gerekli tepkiyi göstermeyen diğer el-Islah üyelerinden farklı duruşu yansitir. ${ }^{84}$

2009 başında Etiyopya'nın Somali'den çekilmesinden bu yana, Damul Cedid şiddet kullanmaktan kaçınarak Somali siyasetinde aktif bir rol üstlenmeyi tercih etmiş ve sonunda Aralık 2016 seçimlerinde parlamentonun iktidar partisi olmuştur. El-Islah'a bağlı Barış ve Kalkınma Partisi'nin

\footnotetext{
82 Hansen ve Mesøy, "The Muslim Brotherhood in the Wider Horn of Africa," 45.

83 "Somalia's Islamists," 14.

84 Counter Extremism Project, "Muslim Brotherhood in Somalia"
} 
(PDP) kurucusu ve başkanı Hassan Şeyh Mahmud, 2012'den 2017'ye kadar Somali'nin Başkanlığını yapmıştır. Mahmud, bu görevi üstlendikten sonra, Somali Federal Hükümeti'nde bazı Damul Cedid üyelerini önemli görevlere atamıştır. PDP, Aralık 2016 parlamento seçimlerinden zaferle ayrılmış ancak Mahmud, Şubat 2017'deki devlet başkanlığı seçimlerinde beklenmedik bir kayıp yaşayarak yerini milliyetçi aday Muhammed Abdullahi Mohamed'e (Fermacu'ya) devretmiştir. ${ }^{85}$

\section{Sonuç}

Tarihsel süreçte Doğu Afrika'nın, İslam'ın farklı akımlarının etkisine açık bir bölge olduğu görülmektedir. Coğrafi ve kültürel yakınlığından dolayı Orta Doğu'nun etkisi bölgede yoğun olarak hissedilmiştir. Doğu Afrika; Suudi fonlarının ve ideolojisinin (selefi-vahhabi) ihrac1, uluslararası radikal ağların, İran'daki İslam Devrimi'nin ve Müslüman Kardeşlerin etkileri bağlamında yoğun rekabetin yaşandığı bir coğrafya olmuştur. Bölgede öteden beri geleneksel sufi İslam ile İslam'in selefi ve vahhabi yorumları arasında bir mücadele yaşanmaktadır.

Müslüman Kardeşler, Doğu Afrika'da Hasan el-Turabi’nin Sudan'daki Ulusal İslami Cephesi'nin militan İslamcı biçiminden Somali'deki modernist ve 1lılmlı el-Islah hareketine kadar farklı biçimler almıştır. Bölgede Müslüman Kardeşler, Sudan'da El-Turabi'nin gölgesinde kalırken, Yemen'de "el-Islah" ismi ile daha çok siyasi faaliyet yürütmüştür. Somali'deki el-Islah ise ülkenin muzdarip kaldığı uzun iç savaş ortamından kaçanlarca kurulmuş ve daha çok 1 lımlı ve sosyal yardım faaliyetleriyle öne çıkmıştır. Bu hareketin ayrıca Mısırlı Müslüman Kardeşlerle güçlü ve yakın bir ilişkisi olduğu görülmüştür. Bu durum, Müslüman Kardeşlerin etkilerinin Mısır'la sınırlı kalmadığını, farklı İslam ülkelerine yayıldığını ve bu etkinin hissedildiği alanlardan birisinin de Doğu Afrika olduğunu göstermektedir.

Somali'de Müslüman Kardeşlerle ilişkili dini gruplar dendiğinde elIslah'ın yanı sıra AIAI'ın da önemli bir yeri olduğu görülmüştür. Ancak eIIslah'1n, gelinen aşamada kökleri Müslüman Kardeşlere uzanan AIAI'dan oldukça farklı olduğu tespit edilmiştir. Parçalı örgüt yapısına sahip olması,

85 Counter Extremism Project, "Muslim Brotherhood in Somalia" 
Turabi'nin çizgisine yakın olması ve daha da önemlisi şiddet yanlısı olması ile bilinen AIAI içinden gelen selefi-vahhabi eş-Şebab ise son yıllarda ismini ülke içinde ve dışında gerçekleştirmiş olduğu saldırılarla duyurmaktadır. Söz konusu saldırılar ise gerek Somali gerekse de Doğu Afrika için istikrarsızlaştırıcı bir etki doğurmaktadır.

\section{Kaynakça}

Abdullahi, Abdurahman M. Meeting Summary: Islamism and Politics in Somalia. Londra: Chatham House, 2012.

Al-Anani, Khalil. "Upended Path: The Rise and Fall of Egypt's Muslim Brotherhood," Middle East Journal 69, no. 4 (2015): 527-543.

Arı, Tayyar ve Engin Koç. "Müslüman Kardeşler Hareketinin Mısır Hükümeti ile Paradoksal İlişkilerinin Analizi: 1931-1970," Dumlupınar Üniversitesi Sosyal Bilimler Dergisi 42 (2014): 225-232.

Baehr, Dirk. "The Somali Shabaab Militias and Their Jihadist Networks in the West," KAS International Reports 8 (2011): 22-38.

Browne, Evie ve Jonathan Fisher. Key Actors Mapping: Somalia. Birmingham, UK: GSDRC, University of Birmingham, 2013.

Cavedon, Matthew. "Men of the Spear and Men of God: Islamism's Contributions to The New Somali State," Emory International Law Review 28, no.1 (2014): 473-508.

Dalar, Mehmet. "Mısır'da Müslüman Kardeşler Hareketinin Demokrasi Anlayışı ve Sisteme Etkisi," Alternatif Politika 1 (2010): 48-73.

de Waal, Alex. Somalia Synthesis Paper. Londra: LSE Conflict Research Programme, (2017): 1-31.

El-Benna, Hasan. Hatıralarım (Müslüman Kardeşler), çev. M. Beşir Eryarsoy, İstanbul: Beka Yayıncılık, 2019.

El-Benna, Hasan. Risaleler, çev. Mehmet Eren ve Mehmet Akbaş İstanbul: Nida Yayıncılık, 2016.

El-Sherif, Ashraf. The Muslim Brotherhood and the Future of Political Islam in Egypt. Washington, DC: Carnegie Endowment for International Peace (2014): 1-34. 
Frampton, Martyn. The Muslim Brotherhood and the West: A History of Enmity and Engagement. Cambridge, Massachusetts: The Belknap Press of Harvard University Press, 2018.

Ganim, İbrahim Beyyümi. "İhvan-1 Müslimin,” Türkiye Diyanet Vakfi İslâm Ansiklopedisi 21, İstanbul: TDV Yayınları, 2000.

Gānim, İbrâhim El-Beyyûmî. "Hasan El-Bennâ," Türkiye Diyanet Vakfi İslâm Ansiklopedisi 16, İstanbul: TDV Yayınları, 1997.

Gürpınar, Bulut. "Toplumsal Hareketler ve Ortak Düşman Algısı: Suriye İhvanı ve HAMAS," Ege Akademik Bakış 18, no. 3 (2018): 331-341.

Hamzawy, Amr ve Nathan J. Brown. The Egyptian Muslim Brotherhood: Islamist Participation in a Closing Political Environment. Washington, DC: Carnegie Middle East Center, 2010.

Hansen, Stig Jarle ve Atle Mesøy. "The Muslim Brotherhood in the Wider Horn of Africa," NIBR Report 33, 2009.

Harnisch, Chris ve Quinn Mecham. "Democratic Ideology in Islamist Opposition? The Muslim Brotherhood's 'Civil State,"' Middle Eastern Studies 45, say1 2 (2009): 189-205.

Holzer, Georg-Sebastian. "Political Islam in Somalia: A fertile Ground for Radical Islamic Groups?," Geopolitics of the Middle East 1, no. 1 (2008): 23-42.

International Crisis Group. "Somalia's Islamists," Crisis Group Africa Report 100, 2005.

Kavas, Ahmet. "Somali," Türkiye Diyanet Vakfi İslâm Ansiklopedisi 37, İstanbul: TDV Yayınları, 2009.

Kfir, Isaac. "Islamic Radicalism in East Africa: Is There a Cause for Concern?," Studies in Conflict \& Terrorism 31, no. 9 (2008): 829-855.

Last, David ve Anthony Seaboyer. "Clan and Islamic Identities in Somali Society," Defence R\&D Canada Report, 2011, 1-110.

Marchal, Roland ve Zakaria M. Sheikh. "Salafism in Somalia: Coping with Coercion, Civil War and its Own Contradictions," Islamic Africa 6, no. 1-2 (2015): 135-163. 
Mitchell, Richard P. The Society of The Muslim Brothers, New York: Oxford University Press, 1993.

Østebø, Terje. "Islamism in the Horn of Africa: Ideology, Actors, and Objectives," International Law and Policy Institute (ILPI) Report (2010): 1-71.

Rabasa, Angel. Radical Islam in East Africa. Santa Monica, CA: RAND Corporation, 2009.

Rubin, Barry. "Comparing Three Muslim Brotherhoods," içinde The Muslim Brotherhood: The Organization and Policies of a Global Islamist Movement, editör: Barry Rubin, 7-18. New York: Palgrave Macmillan, 2010.

Rubin, Barry. "Introduction," içinde The Muslim Brotherhood: The Organization and Policies of a Global Islamist Movement, editör: Barry Rubin, 1-3. New York: Palgrave Macmillan, 2010.

Salih, M. A. Mohamed. "Transnational Islamist (Jihadist) Movements and Inter-State Conflicts,” Nordic Africa Institute: Policy Notes, 2011.

Shay, Shaul. Somalia Between Jihad and Restoration. USA: Transaction Publishers, 2008.

Siradağ, Abdurrahim. "Sahra Altı Afrıkası'nda Terörist Grupların Yükselişi: Boko Haram ve Eş-Şebab,” SETA 125, 2015.

Soage, Ana Belén ve Jorge Fuentelsaz Franganillo. "The Muslim Brothers in Egypt," içinde The Muslim Brotherhood: The Organization and Policies of a Global Islamist Movement, editör: Barry Rubin, 39-56. New York: Palgrave Macmillan, 2010.

Solomon, Hussein. "Political Islam: An African Perspective," Contemporary Review of the Middle East 2, no. 1-2 (2015): 88-103.

Ülger, İrfan Kaya. "Müslüman Kardeşler Teşkilatının İdeolojisi ve Mısır Siyaseti Üzerindeki Etkileri," Kirlkkale Üniversitesi Sosyal Bilimler Dergisi 6, no. 2 (2016): 131-151.

van der Walt, Ruan ve Hussein Solomon. "Histories and Spaces of Terrorism in Africa: The Post-9/11 Strategic Challenge of Somalia's al Shabab," Afro Eurasian Studies Journal 3, no. 1 (2014): 71-99. 
Verhoeven, Harry. "The Gulf and the Horn: Changing Geographies of Security Interdependence and Competing Visions of Regional Order," Civil Wars 20, no. 3 (2018): 333-357.

Weber, Annette. "Eş-Şebab: Allahsız Gençlik," içinde Afrika'da Cihatçıllı: Yerel Sebepler, Bölgesel Büyüme, Uluslararası Işsbirliği, editör: Guido Steinberg ve Annette Weber, 21-44. ORDAF Rapor 15, 2016.

Zollner, Barbara H. E. The Muslim Brotherhood: Hasan al-Hudaybi and Ideology. New York: Routledge, 2009.

\section{Internet Kaynakları}

Abdullahi, Abdurahman M. "The Islah Movement: Islamic Moderation in War-torn Somalia," Son erişim tarihi: 27 Şubat 2021, https://www. hiiraan. com/oct2008/ISLAH.pdf

Abukar, Hassan M. "Turmoil in Al-Islah, Somalia's Muslim Brotherhood," Somali Observer, Son erişim tarihi: 4 Haziran 2020, http:// somalicolumn. blogspot.com/2012/07/turmoil-in-al-islah-somaliasmuslim.html

"Al-Shabaab," Australian National Security, Son erişim tarihi: 2 Haziran 2020, https://www.nationalsecurity.gov.au/Listedterroristorganisations /Pages/Al-Shabaab.aspx

Ataman, Muhittin. "Arap Dünyasında Değişim Talebi Devam Ediyor," Anadolu Ajans1, 23 Aralık 2019, Son erişim tarihi: 27 Şubat 2021, https://www.aa.com.tr/tr/analiz/arap-dunyasinda-degisim-talebidevam- ediyor/1681527

Boukhars, Anouar. "Understanding Somali Islamism," The Jamestown Foundation, Son erişim tarihi: 27 Şubat 2021, https://jamestown.org/ program/understanding-somali-islamism/

Demir, Hilmi. "Aklı Karışıklar İçin Selefilik ve Sünnilik Rehberi," 21 yyte. org, Son erişim tarihi: 16 Şubat 2021, https://www.21yyte.org/tr/ merkezler/ akli-karisiklar-icin-selefilik-ve-sunnilik-rehberi

Munson, Ziad. "Islamic Mobilization: Social Movement Theory and the Egyptian Muslim Brotherhood," The Sociological Quarterly 42, no. 4 (2002): 1-44. https://datascience.iq.harvard.edu/f

"Muslim Brotherhood in Somalia," Counter Extremism Project, Son erişim tarihi: 4 Haziran 2020, https://www.counterextremism.com/content/ muslim-brotherhood-somalia 
